\title{
Streamlining non-governmental organizations' programs towards achieving the sustainable development goals: A conceptual framework
}

\author{
Mohamad Muhyiddin Hassan ${ }^{1,2}$ | Khai Ern Lee Le $^{1,3,4}$ | Mazlin Mokhtar ${ }^{1,4}$
}

${ }^{1}$ Institute for Environment and Development (LESTARI), Universiti Kebangsaan Malaysia, Bangi, Malaysia

${ }^{2}$ Global Environment Centre (GEC), Wisma Hing, Petaling Jaya, Malaysia

${ }^{3}$ Centre for Research and Instrumentation Management (CRIM), Universiti Kebangsaan Malaysia, Bangi, Malaysia

${ }^{4}$ Jeffrey Sachs Center on Sustainable Development, Sunway University, Bandar Sunway, Malaysia

Correspondence

Khai Ern Lee, Institute for Environment and Development (LESTARI), Universiti Kebangsaan Malaysia, UKM 43600, Bangi, Selangor, Malaysia.

Email: khaiernlee@ukm.edu.my

Funding information

Arus Perdana, Grant/Award Number: AP-2015-012; Geran Universiti Penyelidikan, Grant/Award Number: GUP-2017-016

\begin{abstract}
After the launching of sustainable development goals (SDGs), nongovernmental organizations (NGOs) are identified as prominent players in localizing the SDGs. This has drawn attention of the research communities to shift from single-sector approach to cross-sectors approach in achieving the SDGs. However, the different capacity of NGOs is defined by the gaps of institutional factors and different approaches contributing to uncertain impacts that cannot be measured persistently. This limitation has caused many NGOs to choose in maintaining single-sector approach that has been practiced in the millennium development goals previously. Subsequently, this may result to the lack of SDGs output exchange from the NGOs. Therefore, this paper proposes a conceptual framework to streamline NGOs' programs towards achieving the SDGs in two mechanisms, namely, cross-sectors partnerships and broadening social value. Cross-sectors partnerships are developed crossing around the institutional sectors of society as one central partnering process to organize and respond to common issues and concerns in SDGs. Broadening social value is one form of NGO's mechanisms to raise a social interest crossing into many sectors in the role of shifting single-sector approach to cross-sectors approach. This conceptual framework provides a basis for NGOs to plan their programs based on their capability and capacity in achieving the SDGs' target.
\end{abstract}

\section{KEYWORDS}

economic, environment, nongovernmental organizations, social, sustainable development goals

\section{1 | INTRODUCTION}

The sustainable development agenda has spanned across three main eras: pre-Stockholm before 1972, World Commission on Environment and Development, and post-World Commission on Environment and Development after 1987 until Earth Summit in 1992 (Mebratu, 1998). Now, we are in the new era of post-Rio+20, where the countries around the world adopt the new paradigm of United Nations (UN) initiative, namely, sustainable development goals (SDGs), shifting from the predecessor millennium development goals (MDGs) with a deadline of 2015 (Sachs, 2012). In maximizing the trade-offs and output exchanges between the 17 SDGs, it requires to strengthen the efforts towards achieving its targets through the integration of sectoral policies and resilience in governance mechanisms (Biermann, Kanie, \& Kim, 2017). Due to the existence of unpractical policies contradicting to the action-oriented SDGs implementation, the sectoral policies demand an effective translation through shifting from singlesector approach in previous MDGs to cross-sectors approach for SDGs (Boas, Biermann, \& Kanie, 2016; Hazlewood \& Bouyé, 2015). The practicality of integrated sectoral policies revolves around the multiple sectors, consisting four primary institutions, namely, public, business, civil, and academia, as the main participants in the global context to create value through trade-offs and output exchanges between the 17 SDGs. Although SDGs are not legally binding, 
reinstitutionalization process entails an institutional arrangement affecting the organizational capacity of organizations and institutional capacity of multistakeholder coalitions (Biermann et al., 2017). Meanwhile, it will be more aggravating when most SDGs' targets are vague in its social-economic-environment context integration, prompting much space for most nongovernment organization (NGO) actors to claim even though not within their expertise that is in line with what Hopwood, Mellor, and O'Brien (2005) mentioned as de rigueur or timely fashionable for political and business actors.

Such expression of what sector suitably translating the integration of sectoral policies into actions for the institutional factors are appropriately significant in localizing the SDGs from the global into local context, given the civil society represented by NGOs as one of the main participants among other primary institutions in society. NGOs represent a diverse range of organizational interests and they can affect the long-term viability and sustainability of strategic projects (Doh \& Teegen, 2002). The past few years have seen the progress of researches about the participatory of the main primary institutions of society in implementing the global initiatives such as MDGs. The relationships between sectors have been manifested at first through the linear model of science innovation policy including three main sectors being academia, business, and public sectors, represented in the form of "Triple-Helix" (Etzkowitz, 2008). Due to the increasingly intricate challenge transcends the capabilities of any single sector (Kolk, Van Tulder, \& Kostwinder, 2008), Maldonado (2009) proposed the civil sector must be included in the institutional mechanisms when civil society shows its remarks as a potential for enabling the development of new forms of knowledge production to counter the world's most challenging problems. In addition, NGOs were more closely following each UN conference than their respective political arena when the UN conferences were more comprehensive in discussing the issues of sustainability (Turner, 1998). The importance of NGOs was then manifested into new model called "Quadruple-Helix" representing the civil society or civil sector as one participatory domain in SDGs (Maldonado, 2010).

The emerging roles of NGOs from various levels and fields in society have supported the current context of urgency of many researchers to provide the expected roles and considerations of NGOs participating towards achieving the SDGs. Recent researches are much focused on the expected roles and capacities of NGOs or civil society organizations to face the changing trends of sustainable development agenda, being the shifting of MDGs to SDGs. Three main factors affect the capacity of NGOs in delivering their roles in advancing SDGs are (a) uncertainty of funding sources, (b) changing operational capacity, and (c) the melting of NGOs' identity as a nonprofit-based organization (Arhin, 2016). Other researches also exhibit the issues revolving around the NGOs' accountability, lack of effectiveness in the implemented programs, and inappropriate approaches by NGOs in promoting their efforts in specific issues whereby the issues were being framed and limited at the national context to inform the future researches about the gaps of NGOs towards achieving SDGs by year 2030 (Arhin, 2016; Banks \& Hulme, 2012; Hezri, 2016).

Once SDGs are translated into the national context, all sectors are affected by this global initiative. Googins and Rochlin (2000) remarked the global initiative influence by stating "many companies now confronted with the unfamiliar issues related to the role of global entity operating in local communities" as the societal relations become significantly more complex that the primary institutions impacted at their own risks while maintaining their performance. When SDGs now come into the stage of implementation, we should be like-minded and positively playing political games in harmony with what kind of global initiative is. The primary institutions still need to advance it where the intricate global issues arising from the ground require urgent response from the society. Instead of submitting the ceaselessly issues revolving around NGOs, this paper aims to streamlining the existing programs or initiatives conducted by NGOs towards achieving the SDGs as a topic to be focused by NGOs.

By drawing our attention on the streamlining of NGOs' programs and initiatives, the main core advantages of NGOs are that they have the potential to translate the global context of SDGs through localization or in other words through performing action-oriented programs at local community level as they have the potential to translate the social interest crossing the sectors by delivering the diverse range of interest from sectors to return the benefits to the society. Although several researches recommended the cost-cutting programs to advance SDGs at the local level, this paper undertakes the SDGs as a parameter to measure the different NGOs' program mechanisms although each NGO has defined their missions in economic-social-environment dimensions. There are many NGOs with similar goals like achieving the SDGs' targets for the environment as they are environmental NGOs, it does not mean that they have similar program mechanisms to achieve the similar SDGs' targets for environmental protection. The different program mechanisms are actually the difficulties for this civil sector to measure their program impacts in achieving the SDGs' targets that require one framework to streamline their existing programs in order to give benefits towards achieving the SDGs by 2030.

The reality of NGOs playing its role in lifting various benefits crossing many sectors as one form of legitimacy becomes a valuable asset in the eyes of other sectors and communities. This third sector also needs to take into account the constraints and opportunities in determining the gaps of achieving the SDGs that are closely related to their projects at different levels of demographic and geographic structures. Similarly, the implementation of the SDGs at different national contexts and regions should be a platform for all sectors to perform sustainability. Focusing on the NGOs as one sector isolated from other sectors (Googins \& Rochlin, 2000), NGOs have an ability to translate the normative concept of the SDGs into action plans or action-oriented mechanisms in order to play their roles in the SDGs. Hence, there are some major components being used to develop the conceptual framework in streamlining NGOs' programs towards achieving the SDGs. The conceptual framework consists of three substantial subject matters: (a) understanding NGOs as a civil sector, (b) streamlining NGOs' programs mechanisms, and (c) the impacts of NGOs' programs following the SDGs context.

\section{2 | DEVELOPMENT OF CONCEPTUAL FRAMEWORK}

Conceptual framework has been developed as shown in Figure 1 whereby SDGs being the dependent variable that demands response 


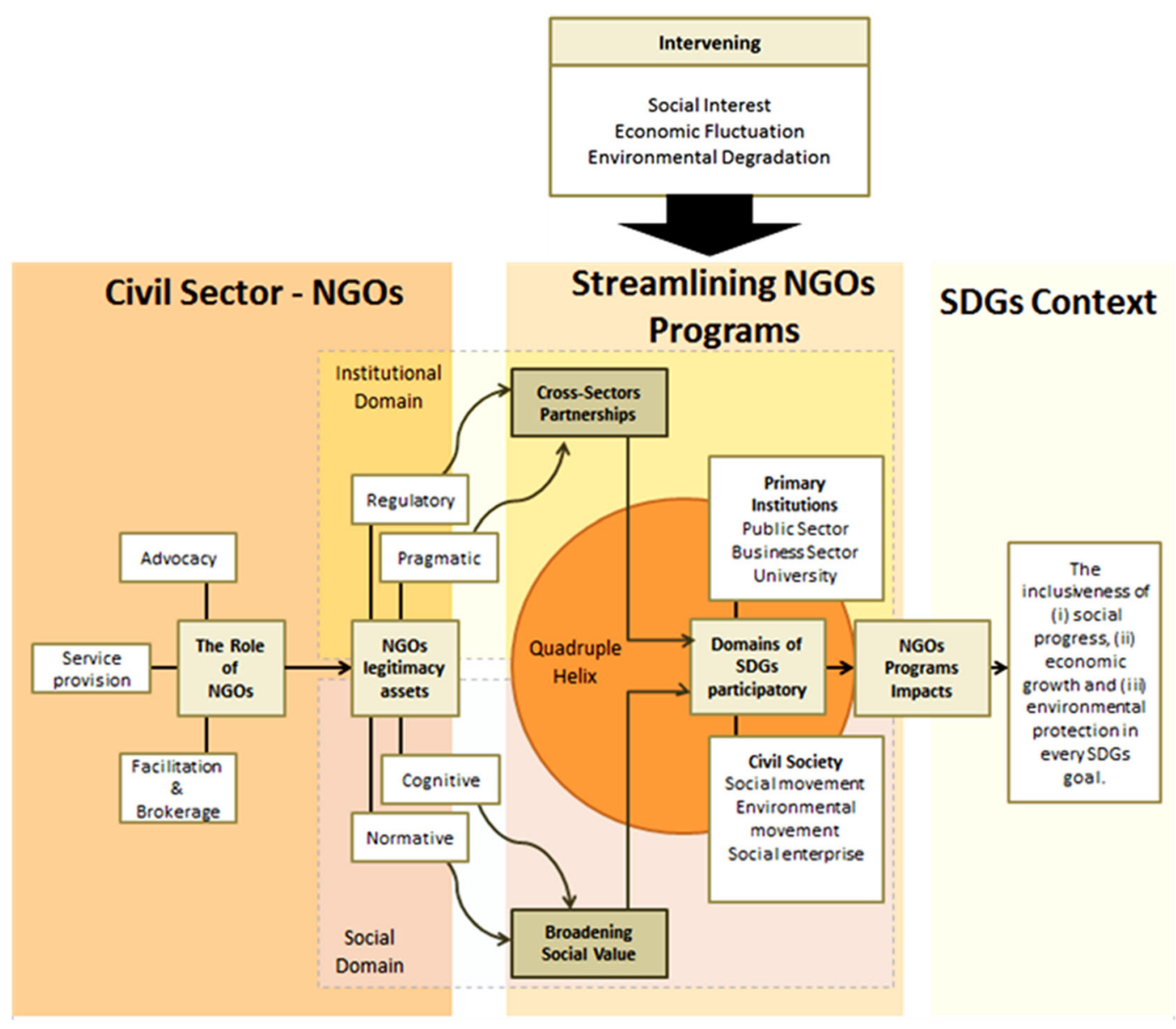

FIGURE 1 Schematic of streamlining NGOs' programs towards achieving the SDGs. NGOs: nongovernmental organizations; SDGs: sustainable development goals [Colour figure can be viewed at wileyonlinelibrary.com]

from four main participants, namely, three from primary institutions (public sector, business sector, and academia) and one from civil society, representing in the form of "Quadruple Helix" model. NGOs or civil sector provides extensive response for the SDGs context through two mechanisms in streamlining NGOs' programs: (a) crosssectors partnerships for institutional domain and (b) broadening social value in explaining the social-economic-environmental movement of civil society.

\section{1 | Understanding the NGOs as a civil sector}

NGOs were firstly phrased by the UN in 1950 (Vakil, 1997). NGOs play their critical roles as a representative of civil society (King, 2009). NGOs are defined as nonprofit-based entities as well as the third sector or civil sector in the national development process, making it a widespread sector in all aspects of society, extending beyond the public and business sectors (Schwartz \& Pharr, 2003).

\subsection{The expected roles of NGOs in the SDGs context}

Arhin (2016) introduced an analytical framework of the expected roles of NGOs in advancing the SDGs into three main roles, namely, advocacy, service provision as well as facilitation, and brokering triggered from the exertions of both Lewis and Kanji (2009) and Banks and Hulme (2012). NGOs' advocacy through the vociferous of NGOs in addressing many issues is a sign of national political maturity (Alatas, 2003). First role of NGOs in advocacy includes the activities of awareness through networking, capacity building, lobbying, and campaigning in the form of action-oriented initiatives either promoting certain interests or outcomes (Unerman \& O'Dwyer, 2006). The second role of NGOs is being a service provider through supplying the basic needs or services to the specific communities (Lewis \& Kanji, 2009). The third role of NGOs is being a facilitator and brokerage in connecting different and diverse range of interests through bringing the participations of actors from socioeconomics and politics to achieve the goals that cannot be achieved alone (Lewis, 2014).

\subsection{The legitimacy assets of NGOs}

The complexity of NGOs' legitimacy structure in defining this third sector has been framed by Lister (2003) that adopted ideas from several authors in different subject matters of NGOs' identities including three key major aspects emphasized in previous study to construct the legitimacy assets of NGOs, namely, accountability, representativeness, and performance. A broad inclusive definition of the NGOs' legitimacy assets crossing many papers was defined by Suchman (1995) as "legitimacy is a generalized perception or assumption that the actions of an 
entity are desirable, proper or appropriate within the socially constructed system of norms, values and beliefs as well as definitions." Lister (2003) also framed the gaps of the three key aspects of legitimacy assets in order to suggest the technical approach of the structures, procedures, and accurate programs that guarantees the legitimacy of NGOs rather than explore those aspects into the contestation of developmental studies literature. Generally, the key asset of NGOs as a civil sector is the public trust where the trust and legitimacy are interlinked concepts (Jepson, 2005).

Adopting the SDGs as a normative concept, Meyer and Scott (1992) defined legitimacy as "the property of a situation or behavior that is defined by a set of social norms as correct and appropriate" where the normative concept of the SDGs is represented in the form of social progress or social movement. The social movement is portrayed by the "qualities and values" came from the recognition of the public trust and legitimacy that is fostered by the individual NGOs (Jepson, 2005). Portraying the social progress, it is prominent to understand the institutional factors or the structures of society. In social science, social structures are illustrated as a socioeconomic stratification with the patterns of large social group relations from individual to organizations or social institutions. In this paper, the legitimacy assets are clustered into two domains of institutional factors, namely, institutional domain and social domain. There are four legitimacy assets of NGOs, whereby two assets being regulatory-pragmatic that are in the institutional domain; whereas the other two assets being normative-cognitive that are in the social domain, as illustrated by Jepson (2005) in his conceptual model linking environmental NGOs' governance-accountability-legitimacy that are adapted from Lister (2003).

In social domain, normative-cognitive legitimacy occupies predominantly in generating social recognition and support for NGOs' role and actions (Jepson, 2005). A normative concept upholds the social values through participation, equal opportunities, social justice, and other rights to be prosecuted (Littig \& Griessler, 2005). Therefore, those social values are endorsed in a normative legitimacy as one prosecution of NGOs to raise the public trust in fulfilling the social needs. Normative legitimacy describes the relationship with wider social and political ideologies concerning the role of charities, NGOs, and civil society in the modern liberal democracy (Jepson, 2005). A cognitive legitimacy through social cognitive theory (SCT) explains the nature of bidirectional reciprocal triadic influences between people-environment-behavior through five basic human capabilities, namely, (a) symbolizing, (b) forethought, (c) vicarious learning, (d) self-regulation, and (e) self-reflection, to set the basic capabilities to trigger the people self-influencing in order to initiate, regulate, and sustain their behavior (Stajkovic \& Luthans, 1998). SCT is based upon but more comprehensive than social learning and/or the behavioral approach to human action. Incorporating the theory into the cognitive legitimacy, those basic capabilities are the strength of cognitive legitimacy and being seen as reasonable to the "eyes" of sectors and society as a social trigger in upbringing the social values prosecuted through the roles and actions of NGOs.

Regulatory-pragmatic legitimacy occupies the cloud of institutional domain. The term "regulatory" covers legitimacy of NGOs' gains from complying with the law and requirements of official bodies in regulating the sector, from supporting the implementation of conventions or official strategies and adopting the professional and operating norms of major institutions (Jepson, 2005). As what discussed by Suchman (1995) and Dart (2004), pragmatic legitimacy rests on the self-interest calculations of the NGOs' most immediate audience and can be visualized through the reality of NGOs playing the role in lifting various benefits or diverse range of interests that is referred to the self-interest calculations. The self-interest calculations mean for which is crossing the institutional factors as one form of legitimacy assets or valuable assets being seen as reasonable in the eyes of other sectors and civil society.

Linking the expected role of NGOs in the SDGs context has the similar intentions with that of Lister (2003) which are the three main aspects of NGOs, being accountability, representativeness, and performances. This paper endeavors to frame the roles of NGOs within the legitimacy assets to describe coherently the mechanisms of NGOs in terms of cross-sectors partnerships in institutional domain and broadening of social value in social domain.

\section{4 | Streamlining NGOs' programs mechanisms}

During the implementation of MDGs, the sectors consisting three primary institutions, namely, public sector, business sector, and civil sector, have given much inputs on the eight goals. Civil sector was represented by NGOs among the main primary institutions in a "Triple-Helix" model together with public sector and business sector (Etzkowitz, 2008). Prior to the end of MDGs implementation, the representativeness of NGOs was replaced by a "Quadruple-Helix" model as civil society organizations whereby Maldonado (2010) proposed the inclusion of academia or universities as a new participating sector in MDGs.

\section{A. Cross-sectors partnerships}

The "Quadruple-Helix" model consists of four main participating sectors, namely, public sector, business sector, civil society, and academia. In converging the inclusiveness of SDGs, all sectors or institutions are responsible to achieve the SDGs. Integrating the "QuadrupleHelix" model within the organizational structures of NGOs, the four main participating sectors are divided into two divisions: primary institutions and civil society. The three primary institutions, namely, public sector, business sector, and university occupy the cloud of institutional domain in accordance to their specific regulations and procedures to bind with the both regulatory-pragmatic legitimacy of NGOs. The broaden discussion on the diverse interests among sectors is pivotal. The institutional environment includes normative, legal, and regulatory elements that organizations must conform to if they are to achieve the legitimacy that is necessary for survival (Powell \& DiMaggio, 2012).

People who want to tackle tough social problems and achieve beneficial community outcomes are beginning to understand the multiple sectors of a democratic society-businesses, nonprofits and philanthropies, medias, communities, and the government-is a way to tackle the robust social problems through cross-sectors 
collaboration to deal effectively and humanely with the challenges (Bryson, Crosby, \& Stone, 2006). In this context, partnership is the vehicle to turn divergent interests into a cauldron of innovation (Googins \& Rochlin, 2000) whereby cross-sectors collaborations are increasingly assumed to be both necessary and desirable as a strategy in addressing many society's most difficult public challenges (Agranoff \& McGuire, 1998; Goldsmith \& Eggers, 2005; Kickert, Klijn, \& Koppenjan, 1997; Mandell, 2001; Rethemeyer, 2005). In the domestic arena, cross-sectors partnerships have become the new tool to mediate the changing roles and perceived responsibilities of what are commonly referred to as the three primary institutional sectors of society, namely, government, business, and the civil sector (Googins \& Rochlin, 2000) including academia as one of the primary institutions. Thus, cross-sectors partnerships can perform as a pluralistic approach for sustainable development governance for SDGs interconnecting the plurality of states, market, and civil society (van Reijl-Rozema, Cörvers, Kemp, \& Martens, 2008).

\section{B. Broadening social value}

There has been arising importance of social value and social impact that were created by various organizations to be measured over the past two decades. Measuring social value has been stipulated by all primary institutions through NGOs' demonstrations of their projects' impact specifically broadening the social value as one impact that can be seen by the legal bodies, corporates, like-minded partners, and engaged communities. Broadening social value is pivotal to be acknowledged as one mechanism to streamline the NGOs' programs. McClintock and Allison (1989) had set the social value as one main essence of the individual variable in a social interdependence for decision making. Messick and McClintock (1968) outlined three orientations of social value, namely, (a) cooperation, (b) individualistic, and (c) competitive, as regular requirements for individuals to make decisions that have consequences not only for their own interest but also for other interests of those around them.

Broadening social value with a social movement, the term "social interdependence" can be referred to the "collective action" that content individuals with social value orientations who take part in collective action seeking to achieve some worthwhile end that they could not be accomplished individually (Teegen, Doh, \& Vachani, 2004). The collective action of a group of individuals is sustained over time in an identifiable way and reflects an important emerging social change and it is termed as social movement (Teegen et al., 2004). The role of social movement is within the institutional environment (Sjöstrand, 1992). A new socioeconomic developmental model is evolving around the roles of institutional environment where relationships between the private, government, and civil sectors play a central role in achieving sustainable communities (Googins \& Rochlin, 2000). When the interests embodied in a social movement evolve structurally to form a free-standing presence within the broader institutional environment, the resulting entity is termed as an NGO (Teegen et al., 2004). The major players in NGOs generally are individuals who contribute time or resources to the organization; NGO's staffs, management, and board members who direct and monitor the organization's activities; and individuals, private foundations, governments, and multilateral institutions that provide funding support (donors). NGOs are accountable to the "clients" they serve-the objects of the social movement or environmental movement or economic mobilization that give rise to the NGO's formation-and their ultimate success is measured by their impact on these clients and their communities (Woller \& Parsons, 2002). Broadening social value looks forward to the positive changes of environmental citizenship from individual to collective behavior of society and institutions. The positive changes are not like what the lacking concept of "fiscal selfinterest approach," a model of human motivation, when a society contributes for their own causing either for virtual rewards and securities applied in an environmental policy taking self-interest as the driver of environmentally sound behavior (Dobson, 2007); instead, the positive changes should appear beyond the concept of "fiscal self-interest approach" as it neglects the public goods' sustenance such as the environment. Therefore, broadening social value can anticipate our selfinterest-centered behavior into a form of commitment to the common good especially the NGOs can use their strength of organizational and institutional capacity to affect their stakeholders and local communities to implement the SDGs becoming one tool of ecological footprint inhibition. Therefore, the broader the environmental citizenship as a social value, the higher the possibility of the SDGs to have positive changes implemented by the NGOs.

\section{5 | NGOs' program impacts towards achieving the SDGs}

If both cross-sectors partnerships and broadening social value mechanisms could streamline the NGOs' programs to achieve the SDGs, three main impacts underlying the SDGs into evaluation are (a) social progress, (b) economic growth, and (c) environmental protection, to be matched within the impacts of NGOs' programs. If we look at 17 SDGs individually, those three impacts are mutually inclusive to each other as illustrated by Le Blanc (2015). What has to be considered are all sectors who involve directly in the NGOs' programs, they need to understand that not all NGOs' program impacts can be claimed as a positive influence in achieving the SDGs. SDGs' targets aim to state the efforts of each SDGs by country whether achieve the targets or vice versa, as this happened previously during the predecessor (MDGs) that it has ambitious eight goals but not all was targeted. The lessons need to be learnt towards 2030 are each SDGs can bring more positive improvement compared with the previous MDGs although not at all goals could be achieved in accordance to its targets by each country. Those three impacts have been stated in the Brundtland's Report that the features of the impacts including environmental protection or ecological balance remain; considering the biosphere to absorb the effects of anthropogenic activities; economic growth contemplating the equity to share resources with the poor and the social progress or social development delivering the human capabilities to fight justice and rights prosecuting the noneconomic or the social equity of human development (Robert, Parris, \& Leiserowitz, 2005).

However, understanding the nature of SDGs' impacts remains a question when the sectors begin to identify their expected roles in 
achieving this current global initiative, especially the NGOs convey the complex social, economic, and physical interventions in which outcomes are burdensome to measure (Nanthagopan, Williams, \& Page, 2016). This creates challenges in monitoring and evaluating the NGOs' programs (Dedu, Staicu, \& Niţescu, 2011) whereby the study also suggested "collaborative social project management capacity" to highly support NGOs in getting proper field level information, sharing knowledge and skills among their stakeholders, undertaking joint-venture NGOs' programs to address the intricate social issues emerging from turbulent natural, economic, and social environment.

NGOs' program impacts resulted from both NGOs' mechanism: (a) cross-sectors partnerships and (b) broadening social value at three different contexts of the SDGs, namely, (a) social progress, (b) economic growth, and (c) environmental protection through adopting "collaborative social project management capacity." When "collaborative social project management capacity" becomes a tool to measure the impacts of NGOs' programs along the cross-sectors partnerships and broadening social value, this may ease NGOs either with singular initiative or multiple initiatives to provide a roadmap towards achieving the SDGs. From singular to multiple initiatives can be manifested through the narrative of NGOs' programs, providing the information related to the social progress, economic growth, and environmental protection. The roadmap emphasizes the advantages of both cross-sectors partnerships and broadening social value through the evaluation of existing NGOs' programs in order to be streamlined in achieving the SDGs. There are two possibilities suggested in this paper to give the descriptive NGOs' program impacts translated into three main contexts of SDGs. First, being the categorization of 17 goals into three different contexts of the SDGs and second, being each NGOs' program or initiative is described in three contexts of the SDGs even though achieving only one goal of the SDGs. There is a requirement for further development of conceptual framework that is choosing between both mechanisms of the NGOs' program impacts to achieve the SDGs following the inclusiveness of each goal based on the three contexts of the SDGs.

\subsection{The gaps of streamlining NGOs' programs towards achieving the SDGs}

Those three impacts may be the opportunities for NGOs to streamline their contributions in achieving the SDGs, whereas each pillar of sustainability issues to be confirmed may become the intervening aspect for the NGOs to maintain their accountability, representativeness, and performance. Exploring the sustainability issues can be categorized into three gaps: (a) social interest, (b) economic fluctuation, and (c) environmental degradation.

Social interest was defined by Adlerian's theory as "a feeling of community, an orientation to live cooperatively with others, and a lifestyle that values the common good above one's own interests and desires" (Adler, 1970). Due to the diverse range of social interest from individuals to the institutional factor, the NGOs may have stuck between the local interests in the project sites while balancing the political interests in binding with the official requirements from the official bodies, corporates, and executive partners. Those interests revolve around the institutional factor that may affect the performance of NGOs in delivering their commitments to each of their stakeholders. Although the capacity of NGOs remains as free-standing organization in accordance to the sector failure, it does not mean the NGOs are playing major roles of other sectors until this affect catastrophe on their performance. Sector failure, though environmental factors can greatly affect the formation of all interorganizational relationships, cross-sectors collaborations in particular appear to be influenced by the degree to which single effort to solve a public problem has failed. Sector failure refers to the often-observed situation that single-sector efforts to solve a public problem are tried first and found before cross-sectors efforts are attempted. The situation looks similar with the sector domination on other sectors as pictured by Googins and Rochlin (2000) as well as NGOs would find some budgets from other sectors to survive which at the same time they need to fulfil what should be other sectors putting on their roles in a society. However, it is undeniable that there would be NGOs lacking of their accountability in their networking to pertain the social interests through service provision. Instead of the exploitation among sectors, the roles of NGOs through its legitimacy should streamline the diverse social interests in an institutional factor to achieve the SDGs.

As a nonprofit organization, the NGOs depend on other sectors for financial support. Economic fluctuation is also contemplated as one gap in advancing the SDGs when the national income of a country rises meaning the economy is growing or vice versa. The survival of NGOs sometimes gets tangled with the corporate's profit performance although their region have a growing economy whereby sometimes NGOs face discontinuous donations from their funders or legal bodies due to the internal problems of their stakeholders. In terms of environmental degradation, the resources scarcity is subjected as one effect of the environmental degradation. In maintaining resources, NGOs face uncontrolled phenomenon of environmental degradation that is testing the limit of organizational capacity and technical strength to convince their stakeholders. Besides under the pressure of their stakeholders, NGOs also face shrinking trust from citizens who get involved directly into their projects.

Such obligations to foster both new mechanisms, cross-sectors partnerships and broadening the social value, are seen as reasonable in combating the challenging issues of the social interest, economic fluctuation, and environmental degradation faced by NGOs corresponding to the aims of the SDGs in combating the intricate sustainability issues. Once responsible institutions to prosecute the rights of society seem neglecting the social interest as the society is very much dependence on them to protect their interests (Putnam, 2004) with additional competitive and institutional pressures that significantly affect their formation as well as long-term sustainability (Oliver, 1990; Sharfman, Barbara, \& Yan, 1991) may propose both mechanisms to shift towards multisectoral approach.

\section{I CONCLUSION}

A conceptual framework has been proposed in this paper to streamline NGOs' programs towards achieving the SDGs through two mechanisms endorsing the diverse interests from multiple-sectors 
and civil society, namely, (a) cross-sectors partnerships and (b) broadening social value by NGOs. This framework is conceptualized based on the framework of previous study, structuring the roles and legitimacy assets of NGOs that sees NGOs to have a value creation on their legitimation process to their stakeholders. There are numerous publications attempt to frame the different contexts of NGOs by social purpose, membership, advocacy, and operational capacity as the local, state, or international NGOs. Generally, the conceptual framework of this paper is a cross idea from those publications to define a clear progress of NGOs using their both mechanisms to achieve the SDGs. The institutional-organizational-stakeholder theories are applied in this study to understand the nature of cross-sectors partnerships among the sectors' collaboration with the NGOs. The SCT is applied to describe the broadening of social aspects by NGOs through the social movement, environmental movement, and economic mobilization by the civil society. In evaluating NGOs' program impacts, the mechanisms of streamlining NGOs' programs is depending on the inclusiveness of three different contexts of the SDGs, namely, (a) social progress, (b) environmental protection, and (c) economic growth encompassed in each of the 17 SDGs through utilizing "collaborative project management capacity" as one approach to assess the NGOs' program mechanisms in achieving the SDGs. Thus, the integrative idea between the three substantial subject matters, namely, (a) understanding the NGOs as a civil sector, (b) streamlining NGOs' programs mechanisms, and (c) the impacts of NGOs' programs following the SDGs context.

\section{ACKNOWLEDGMENTS}

The authors would like to acknowledge the financial support for this study provided by Universiti Kebangsaan Malaysia through Geran Universiti Penyelidikan (GUP-2017-016) and Arus Perdana (AP-2015-012).

\section{ORCID}

Khai Ern Lee (D) http://orcid.org/0000-0002-1463-3787

\section{REFERENCES}

Adler, A. (1970). Superiority and social interest: A collection of later writings. Evanston, Illinois, USA: Northwestern University Press.

Agranoff, R., \& McGuire, M. (1998). Multinetwork management: Collaboration and the hollow state in local economic policy. Journal of Public Administration Research and Theory, 8(1), 67-91. https://doi.org/ 10.1093/oxfordjournals.jpart.a024374

Alatas, S. M. (2003). The role of NGOs and non-state actors in Malaysia's foreign policy formulation during the Mahathir Era. Akademika, 62(1), 59-84.

Arhin, A. (2016). Advancing post-2015 sustainable development goals in a changing development landscape: Challenges of NGOs in Ghana. Development in Practice, 26(5), 555-568. https://doi.org/10.1080/ 09614524.2016 .1189513

Banks, N., \& Hulme, D. (2012). The role of NGOs and civil society in development and poverty reduction. Brooks World Poverty Institute Working Paper No. 171. https://doi.org/10.2139/ssrn.2072157

Biermann, F., Kanie, N., \& Kim, R. E. (2017). Global governance by goalsetting: The novel approach of the UN sustainable development goals. Current Opinion in Environmental Sustainability, 26, 26-31. https://doi. org/10.1016/j.cosust.2017.01.010
Boas, I., Biermann, F., \& Kanie, N. (2016). Cross-sectoral strategies in global sustainability governance: Towards a nexus approach. International Environmental Agreements: Politics, Law and Economics, 16(3), 449-464. https://doi.org/10.1007/s10784-016-9321-1

Bryson, J. M., Crosby, B. C., \& Stone, M. M. (2006). The design and implementation of cross-sector collaborations: Propositions from the literature. Public Administration Review, 66, 44-55. https://doi.org/ 10.1111/j.1540-6210.2006.00665.x

Dart, R. (2004). The legitimacy of social enterprise. Nonprofit Management \& Leadership, 14(4), 411-424. https://doi.org/10.1002/nml.43

Dedu, V., Staicu, G., \& Niţescu, D. C. (2011). A critical examination of foreign aid policy. Why it fails to eradicate poverty? Theoretical \& Applied Economics, 18(4), 37-48.

Dobson, A. (2007). Environmental citizenship: Towards sustainable development. Sustainable Development, 15(5), 276-285. https://doi.org/ $10.1002 /$ sd.344

Doh, J. P., \& Teegen, H. (2002). Nongovernmental organizations as institutional actors in international business: Theory and implications. International Business Review, 11(6), 665-684. https://doi.org/ 10.1016/S09695931(02)00044-6

Etzkowitz, H. (2008). The triple helix: University-industry-government innovation in action (1st ed.). New York: Routledge.

Goldsmith, S., \& Eggers, W. D. (2005). Governing by network: The new shape of the public sector. Washington, DC: Brookings Institution Press.

Googins, B. K., \& Rochlin, S. A. (2000). Creating the partnership society: Understanding the rhetoric and reality of cross-sectoral partnerships. Business and Society Review, 105(1), 127-144. https://doi.org/ 10.1111/00453609.00068

Hazlewood, P., \& Bouyé, M. (2015). Sustainable development goals: Setting a new course for people and planet. Washington, D.C.: World Resources Institute. Retrieved from: https://www.wri.org/blog/2015/09/sustainable-development-goals-setting-new-course-people-and-planet

Hezri, A. (2016). The sustainability shift: Refashioning Malaysia's future. Penang: Areca Books.

Hopwood, B., Mellor, M., \& O'Brien, G. (2005). Sustainable development: Mapping different approaches. Sustainable Development, 13(1), 38-52. https://doi.org/10.1002/sd.244

Jepson, P. (2005). Governance and accountability of environmental NGOs. Environmental Science \& Policy, 8(5), 515-524. https://doi.org/ 10.1016/j.envsci.2005.06.006

Kickert, W. J., Klijn, E. H., \& Koppenjan, J. F. (Eds.) (1997). Managing complex networks: Strategies for the public sector. London: Sage.

King, M. (2009). King code of governance for South Africalnstitute of Directors of South Africa.

Kolk, A., Van Tulder, R., \& Kostwinder, E. (2008). Business and partnerships for development. European Management Journal, 26(4), 262-273. https://doi.org/10.1016/j.emj.2008.01.007

Le Blanc, D. (2015). Towards integration at last? The sustainable development goals as a network of targets. Sustainable Development, 23(3), 176-187. https://doi.org/10.1002/sd.1582

Lewis, D. (2014). Understanding the role of non-government organizations (NGOs) as cultural brokers: A review of approaches. Osterreichische Zeitschrift fur Volkskunde, 3, 293-298. ISSN 0029-9669

Lewis, D., \& Kanji, N. (2009). Non-governmental organizations and development. London: Routledge.

Lister, S. (2003). NGO legitimacy: Technical issue or social construct? Critique of Anthropology, 23(2), 175-192. https://doi.org/10.1177/ $0308275 \times 03023002004$

Littig, B., \& Griessler, E. (2005). Social sustainability: A catchword between political pragmatism and social theory. International Journal of Sustainable Development, 8(1-2), 65-79. https://doi.org/10.1504/ IJSD.2005.007375

Maldonado, V. (2009). The role of higher education in a new quadruple helix context. Higher education and civic engagement partnerships-Create, 
challenge, change conference (NUI Galway). Dublin: Croke Park Conference Centre.

Maldonado, V. (2010). Achieving the MDGs through quadruple helix partnerships: University-government-industry-third sector collaborationGlobal University Network for Innovation. Retrieved from: http://www. guninetwork.org/articles/achieving-mdgs-through-quadruple-helixpartnerships-university-government-industry-third

Mandell, M. P. (Ed.) (2001). Getting results through collaboration: Networks and network structures for public policy and management. California: ABC-CLIO.

McClintock, C. G., \& Allison, S. T. (1989). Social value orientation and helping behavior 1. Journal of Applied Social Psychology, 19(4), 353-362. https://doi.org/10.1111/j.1559-1816.1989.tb00060.x

Mebratu, D. (1998). Sustainability and sustainable development: Historical and conceptual review. Environmental Impact Assessment Review, 18(6), 493-520. https://doi.org/10.1016/S0195-9255(98)00019-5

Messick, D. M., \& McClintock, C. G. (1968). Motivational bases of choice in experimental games. Journal of Experimental Social Psychology, 4(1), 1-25. https://doi.org/10.1016/0022-1031(68)90046-2

Meyer, J. W., \& Scott, W. R. (1992). Organizational environments: Ritual and rationality. Beverly Hills: Sage Publications, Inc.

Nanthagopan, Y., Williams, N. L., \& Page, S. (2016). Understanding the nature of project management capacity in Sri Lankan nongovernmental organisations (NGOs): A resource based perspective. International Journal of Project Management, 34(8), 1608-1624. https://doi.org/10.1016/j.ijproman.2016.09.003

Oliver, C. (1990). Determinants of interorganizational relationships: Integration and future directions. Academy of Management Review, 15(2), 241-265. https://doi.org/10.5465/amr.1990.4308156

Powell, W. W., \& DiMaggio, P. J. (Eds.) (2012). The new institutionalism in organizational analysis. Chicago \& London: University of Chicago Press.

Putnam, R. D. (2004). Democracies in flux: The evolution of social capital in contemporary society. New York, USA: Oxford University Press.

Rethemeyer, R. K. (2005). Conceptualizing and measuring collaborative networks. Public Administration Review, 65(1), 117-121. https://doi. org/10.1111/j.1540-6210.2005.00436.x

Robert, K. W., Parris, T. M., \& Leiserowitz, A. A. (2005). What is sustainable development? Goals, indicators, values, and practice. Environment: Science and Policy for Sustainable Development, 47(3), 8-21. https:// doi.org/10.1080/00139157.2005.10524444

Sachs, J. D. (2012). From millennium development goals to sustainable development goals. The Lancet, 379, 2206-2211. https://doi.org/ 10.1016/S0140-6736(12)60685-0

Schwartz, F. J., \& Pharr, S. J. (2003). The state of civil society in Japan. The Edinburgh Building, Cambridge: Cambridge University Press.
Sharfman, M. P., Barbara, G., \& Yan, A. (1991). The context of interorganizational collaboration in the garment industry: An institutional perspective. The Journal of Applied Behavioral Science, 27(2), 181-208. https://doi.org/10.1177/0021886391272003

Sjöstrand, S. E. (1992). On the rationale behind "irrational" institutions Journal of Economic Issues, 26(4), 1007-1040. https://doi.org/ 10.1080/00213624.1992.11505360

Stajkovic, A. D., \& Luthans, F. (1998). Social cognitive theory and selfefficacy: Going beyond traditional motivational and behavioral approaches. Organizational Dynamics, 26(4), 62-74. https://doi.org/ 10.1016/S0090-2616(98)90006-7

Suchman, M. C. (1995). Managing legitimacy: Strategic and institutional approaches. Academy of Management Review, 20(3), 571-610. https://doi.org/10.5465/amr.1995.9508080331

Teegen, H., Doh, J. P., \& Vachani, S. (2004). The importance of nongovernmental organizations (NGOs) in global governance and value creation: An international business research agenda. Journal of International Business Studies, 35(6), 463-483. https://doi.org/10.1057/palgrave. jibs.8400112

Turner, S. (1998). Global civil society, anarchy and governance: Assessing an emerging paradigm. Journal of Peace Research, 35(1), 25-42. https://doi.org/10.1177/0022343398035001003

Unerman, J., \& O'Dwyer, B. (2006). On James bond and the importance of NGO accountability. Accounting, Auditing \& Accountability Journal, 19(3), 305-318. https://doi.org/10.1108/09513570610 670316

Vakil, A. C. (1997). Confronting the classification problem: Toward a taxonomy of NGOs. World Development, 25(12), 2057-2070. https:// doi.org/10.1016/S0305-750X(97)00098-3

van Reijl-Rozema, A., Cörvers, R., Kemp, R., \& Martens, P. (2008). Governance for sustainable development: A framework. Sustainable Development, 16(6), 410-421. https://doi.org/10.1002/sd.367

Woller, G., \& Parsons, R. (2002). Assessing the community economic impact of nongovernmental development organizations. Nonprofit and Voluntary Sector Quarterly, 31(3), 419-428. https://doi.org/10.1177/ 0899764002313006

How to cite this article: Hassan MM, Lee KE, Mokhtar M. Streamlining non-governmental organizations' programs towards achieving the sustainable development goals: A conceptual framework. Sustainable Development. 2019;27: 401-408. https://doi.org/10.1002/sd.1912 